\title{
Nurturing the Fourth Generation: Defining the Historical Mission for Our Generation
}

\author{
Mshaï S. Mwangola*
}

\begin{abstract}
Reflections on the African academy have identified different generations of African scholars. These interventions have sought to using different criteria, identifying different foci and arguing the importance of each. This paper furthers Thandika Mkandawire's reflection on the first three generations of the post-colonial era (1995) by suggesting a historical mission for the next, the emerging fourth generation.

\section{Résumé}

Les réflexions sur l'Académie africaine ont identifié différentes générations de chercheurs africains. Ces interventions ont cherché à utiliser des critères différents, à identifier les différents centres d'intérêt et à discuter de l'importance de chacun. Ce document élargie la réflexion de Thandika Mkandawire par rapport aux trois premières générations de la période postcoloniale (1995) en suggérant une mission historique pour la prochaine, la quatrième génération émergeante.
\end{abstract}

How are we nurturing the next generation?-Takiyawaa Manuh

Each generation must out of relative obscurity, discover its mission, fulfil it, or betray it.-Frantz Fanon

Celebrations are almost always joyous occasions, and CODESRIA's 30th anniversary is certainly no exception. I think that the Council has justifiable reason to take pride in the achievements of thirty years. Celebrations should also provide the opportunity to carefully and responsibly take stock of the challenges of the present, which are the legacy of the past and the foundation for the future. In the spirit of collective reflection that Ayi Kwei Armah calls 'cerebration', this is an intervention focusing on the emerging genera-

* Department of Performance Studies, Northwestern University, Evanston, IL, USA. 
tion of African intellectuals, those who, following Thandika Mkandawire's identification of three preceding generations of African scholars trained in the 'post-independence' era, have been identified as the fourth generation. ${ }^{1}$

In the recent past, CODESRIA has placed much emphasis on the issue of intergenerational participation in its programmes. This has resulted in concerted efforts being made to ensure the participation of all four generations in the activities of the Council. Of particular significance are CODESRIA programmes for emerging scholars. Initiatives such as CODESRIA's 'small' grants for thesis-writing and prizes for doctoral dissertations are invaluable in both enabling and recognising quality graduate work in African universities. The new CODESRA series, 'Interventions', promises to further increase the visibility of the work of younger scholars and entrench their contributions.

While the presence of the fourth generation has been recognised, it is still yet to be defined, except by default. Mkandawire's reflection on the first three generations, based as it is on a retrospective analysis of characteristics already manifested within the African academy, is silent on this still emerging generation. Ebrima Sall et al. (2003), who have re-examined these three generations, are also silent on the nature of the fourth generation of African scholars. I suggest we begin to actively 'imagine it into being', articulating what we already know to be its reality even as we shape the direction(s) we envision it to take.

In his now classical treatise on the reality and legacy of colonialism, The Wretched of the Earth, Frantz Fanon urges us to seize the initiative for each historical era, by adopting a generational agenda to the challenges we face (1967: 166). Whether we like it or not, each generation of people - and that must include its intellectuals as well-are born into a specific context that presents peculiar challenges. The scholarship of preceding generations of African scholars clearly reflects the eras in which they worked. Discourses on decolonisation, for example, can be used to trace the trajectory of that historical struggle, from its earliest phases of resistance, through different stages of the liberation struggles, to the manifestation of diverse experiences of political independence in the continent. In the present academic environment, these discourses continue in different guises, hence the re-emergence of similar theoretical arguments in first, discussions on neo-colonialism, and now in the debates on globalisation. A comparative analysis of important works by African intellectuals from different historical periods shows that, stripped of the specificities of the particular debates, Africa's intelligentsia has continued over different eras to respond more or less to the same core concerns, such as identity definition and the continent's complicated relationship to the rest of the world. One cannot also ignore the prevailing socio- 
political contexts and the accompanying economic environment that proved crucial factors in determining the nature of the African academy and had enormous impact on the choices undertaken by intellectuals, including the important question of who stayed, and who left. As Mkandawire demonstrates, while it is possible to demarcate between the generations from the point of view of their scholarship and the focus of their work, the conditions within which they have to work has also influenced their scholarship. The first generation generally returned home after graduate studies abroad to job security as well as other material and moral incentives. They had a relatively good working relationship with the state and have maintained an influential presence in the global academy, while inaugurating new networks and institutions aimed at developing and strengthening the African academy. In contrast, the second generation tended to stay or return abroad due to the growing disenchantment with the working environment at home, a hostile relationship with the state and /or their own marketability abroad. Highly mobile, they remain an influence in intellectual circles everywhere but in Africa. The third generation largely trained in an era characterised by difficult socio-political and economic circumstances, which negatively impacted the African institutions in which they studied. It has marginal presence in the global academy, and has focused its energies within the continent, shouldering the logistical burden of qualitative transformation of the African academy. Recognising the influence that each of these generations has had on the present, I submit that it is important that the fourth generation understands how the specific contexts, constraints, challenges and possibilities of this present moment influences it towards the discovery, planning and implementation of the historical mission that will be its own legacy to the future.

This paper is an invitation to cerebration — calling forth an engagement with issues emanating from the identification and articulation of a collective mission for this fourth generation. In recognising the importance of selfarticulation in initiatives of this nature, this paper is first directed to those who self-identify as members of this fourth generation as I do. We are the ones who ultimately will be held accountable for the commission of the mission we choose to adopt. Secondly, it is directed to all others who, in recognising the fourth generation as part of a continuum stretching from the first African scholars to those who are still the unrealised dreams of the future, are willing to commit themselves to its nurture.

I wish to emphasise the desirability and validity of bringing into this conversation a diversity of individual and group experiences, all of whom can and should contribute to this discussion. As an African female graduate student currently located in a non-African institution, I am well aware of the challenges of speaking from what is commonly perceived to be the margin. 
I do recognise however the irony of my position; the very attributes some use to define me as marginal, are viewed by others as proof of my privileged status. The perspective that I bring to this discussion is both shaped by who I am, and conversations with other scholars of the fourth generation. ${ }^{2}$

\section{Defining a Mission}

In conversations on the issue of generational affiliation preceding the anniversary conference, I became aware that the majority of those I spoke to who self-identified with the fourth generation did so by default. Unable to locate themselves even generally within any of the categories identified by Mkandawire (1995), they were sceptical about the possibility of a definitive ethnography that captured the fourth generation since, as several pointed out, this is a generation that is still emerging, still in the initial stages of consolidating itself. In response to these conversations, I have decided to approach the question of generational definition from another direction. Fanon challenges us to the articulation of a collective definition of mission and agenda, emanating out of a careful examination of the peculiarity of the historical context within which a generation finds itself. It is certainly useful to look back a point in time and identify this kind of historical mission with the benefit of hindsight as Mkandawire does. However, I believe Fanon is rather proposing that this be carried out much earlier, at the point where a generation is emerging onto the scene, when it still has a measure of control in consciously determining the direction its future will take. I would like to propose as this mission the centring of African communities in intellectual production on and of Africa. In conceptualising this shift of knowledge generation, creation, transmission and retention from place (Africa as the object of research) to people (Africans as creators and consumers of knowledge) I argue for a focus on two key areas: the place of African scholarship and the validation of African epistemologies.

The first challenge for the fourth generation is to bring about the recognition of Africans as the premier producers and consumers of knowledge on and emanating from Africa. This includes both those working within the academy and other intellectuals who prefer or are forced to use other spaces. The focus of this paper is on African academics, but it is important to also observe the need for those within the academy to recognise as equal partners organic intellectuals working outside. African communities will not truly be centred in our work until we develop the kind of co-operative relationships beyond the academy, envisioned for example in Ayi Kwei Armah's epistemic novel, Kmt: In the House of Life in which a productive partner- 
ship between the university academics and 'traditionalists' is set into motion by this frank admission on the part of the former:

[W]e are seeking to knock holes in the walls separating us. You have been imprisoned behind walls labelled tradition. We are often not aware that we too lie behind walls that far from making a home, merely make a prison called modernity. We need not just to knock holes in these obsolete walls; we need to knock them down completely. We need not only to touch each other through permissive holes; we need to embrace each other in the fullness of liberating possibility. Working together, living together. No doubt dozens of scholars have come to [traditionalists] in the past, also talking work. But this is what we mean: we are not here to invite you to ... hand ... over your knowledge to us, so we can go and sell it for the professor's salary or the expert's reputation in the world made by pillagers. We would like to sit with you, eat with you, sleep with you, lie with you, in short share everything with you, so that together we can bring your knowledge and ours into one stream ... That your knowledge is precious, we know ... We hope together with you, to create books, films, songs, the many objects in which knowledge can be contained and carried. Each object will bear the names of all who work together to create it. Yours, ours. When sold, these books and objects will make money for the authors and manufacturers, while spreading the knowledge of our own throughout the world. Our method with you will be to share the money and the acknowledgment equally, the same way we share the work. Possibly, in the past, when university scholars came to invite you to work with them, they rearranged things in such a way that you had nothing to do with the making of decisions ... This time what we propose is this: let us meet here to decide together... (Armah 2002: 137-138).

This passage is worth quoting at length because it goes to the heart of a problem deeper than a mere difference in location. As Armah further points out in the novel, it is a question of learning to put aside a long history of suspicion and disrespect, which has grown out of a deliberate distancing of not only different knowledge systems, but also people. If we were honest with ourselves, we would admit that this is a history that has been characterised all too often by exploitation by academics, especially in partnerships with those working within indigenous institutions and systems. These are far too often indistinguishable from the kind of unequal relationships we ourselves rail against, when we talk about being short-changed by scholars from the global North.

General recognition of the work of African academics is long overdue, both from within our own societies and from outsiders. The African academy has been generally sidelined from important decision-making processes by state governments. In countries such as Kenya, independent research 
and policy institutes and consultants are thriving as alternative resource bases for the formulation of national policy. ${ }^{3}$ The clichéd metaphor of the university as an ivory tower far removed from 'real life' remains unchallenged as the dominant perspective of the academy in most African societies (Sall Lebeau and Kassimir 2003: 138). ${ }^{4}$ That this view persists, despite tangible evidence of academic involvement in engaging societal challenges, is verification for the need for an aggressive public relations campaign to dispel the costly illusion that universities are 'superfluous and dispensable' (Mkandawire 1997: 18).

Even inside academia, the problem exists. Within the very institutions in which they teach, the work of African scholars is often subordinated to that of their Western peers. While this could be because their African colleagues are unfamiliar with it for a variety of reasons, including publication location and unavailability of resources, I suggest that it is rather because African scholarship is too often unjustly devalued and sometimes even denigrated in comparison to that of Western scholars. The continuing struggle to decolonise the mind of many African academics is evident in publications and presentations that engage Western work almost exclusively with only token acknowledgement (if any) of African scholarship. This is an indictment of our complicity in the still unequal relationship between the African and Western academies. On the international scene, the situation is even grimmer; ' $[w] \mathrm{e}$ are probably the only part of the world about which it is still legitimate to publish, without reference to local scholarship' (Mkandawire 1997: 29). While several African intellectuals of preceding generations have fought battles for the recognition of African scholarship in the global knowledge society, the challenge for the emerging generation of scholars is to complete the move, in the words of Micere Githae Mugo, 'from the periphery to the centre' of African Studies scholarship (Mugo 1996: 38).

Moving to the centre of African Studies scholarship entails both the recognition of the quality and quantity of work being done by African scholars, and the transformation of the all too familiar unequal division of labour in international academic partnerships. African researchers are too often relegated in credit even if not in reality to the position of 'watu wa mikono'mere hirelings - carrying out the tedious field labour of research, while their Western counterparts do the 'brain work' of analysis and synthesis. No prizes for guessing who is credited with the resulting theoretical insights. This project must begin with collapsing into one the two sites, local and international, of present African Studies. By virtue of both quality and quantity, local scholarship ought to be recognised as the benchmark by which all other work in African Studies is evaluated. For this to happen, we must take 
responsibility for the quality of the work produced within African institutions, honestly assessing strengths and weaknesses and attending to them. Where there is legitimate critique of lack or oversight, steps must be taken to redress the situation. Secondly, research agendas and directions must be determined within the continent, by the needs, priorities and perspectives of the communities at the centre of these studies as both subjects and premier beneficiaries. Thirdly, this project must clearly insist on due credit being given to those otherwise invisible thinkers whose work is often 'stolen', ignored or dismissed as irrelevant or unimportant by academic gatekeepers. As Mkandawire put it, in this global era of academic networking, we must begin to combine the 'working' and 'netting' rather than acquiescing to the age-old division of labour in which Africans do the 'working' while westerners do the 'netting'.

On another level, this also means recognising a wider audience for the work that African academics produce. We must actively change the situation where no one else beyond the small circle of other scholars whose job it is to read the work we produce is familiar with it. We must therefore make intellectual discourse emanating from and for African communities accessible to different audiences, taking account of prevailing circumstances existing within and outside the academy.

The difficulties facing African academics are well documented. Beyond the financial restraints that make it difficult for many to publish, it is common knowledge that several have been forced to even flee into exile or to work in severely restricted circumstances, due to unwarranted state censorship and other forms of harassment. ${ }^{5}$ Some intellectuals have given in to this intimidation. ${ }^{6}$ Many others have chosen instead to disguise their interventions by finding alternative forums, such as embodied performance sites, which are generally more difficult to police or censor. ${ }^{7}$ As John Ruganda observes in his study of Francis Imbuga's social satires, the challenge has often been to find a way to tell the truth but to do so in a way that protects it from vilification and the teller from incarceration (Ruganda 1992: xxi).

Even where and when academics have the freedom to work as they please, it is often the case that this work remains inaccessible to those to whom it should most matter. Some have deliberately eschewed scholarly forums in order to reach those who find academic publications inaccessible for reasons of dissemination location or choice of linguistic register. Social commentators Francis Imbuga, Wahome Mutahi and Kwesi Yankah have thus earned the accolade of public intellectual, not so much from their scholarly publications as from their dramatic and journalistic endeavours. ${ }^{8}$ Embracing our own societies as the primary audiences for our work produces 
the challenge of finding ways of making it accessible, and where necessary, finding appropriate ways of addressing different audiences, without diluting the essential content.

The second challenge for the fourth generation is of an epistemological nature. It involves the rediscovery, development, recognition and validation of African epistemologies in the creation and transmission of knowledge. This needs to happen in both the studying of issues specific to Africa and those of a universal nature. I am calling on the fourth generation to re-define and re-design the terms of engagement between Africa's intelligentsia and that of the rest of the world. We need to prioritise our own endogenous methodologies of generating, sharing, transmitting and storing knowledge, with no apologies for the fact that these will sometimes differ from those of other societies. Instead of relying solely on epistemologies validated by other academies, we need to use these to complement our own. It is time that we each came to the realisation that our 'training as a social scientist [may be] inadequate to the task of studying the subjugated knowledge of a Black ... standpoint', leading us to the empowering space opened up 'by using alternative ways of producing and validating knowledge' (Collins 2002: 252).

More and more, African intellectuals and institutions such as CODESRIA are insisting on having a significant say in the choice and direction of research priorities, even though these sometimes do continue to be determined by funding 'partners' who are more likely to be influenced by the World Bank, IMF and UN 'experts' at the expense of local knowledge and needs. But the focus on agenda, while important, is not enough. We need to reexamine the interpretative frameworks and research methodologies that we use to carry out our research. In what ways do these paradigms and strategies reflect the contexts in which we work, the resources we have available and the people with whom and for whom we are working? Are they able to accurately change to accommodate, in particular, work with communities whose subjugated knowledge has long evaded and defied traditional forms of Western knowledge? Do they 'overcome the legacies of both the epistemological violence and the paradigmatic limitations bequeathed' us by existing hegemonies controlling our production of knowledge? ${ }^{9}$ Until we are able to use our own epistemologies in our pedagogy and research, we will continue to marginalise our own communities, voices and issues to the ultimate detriment of our continent.

The importance of embodied and material performance as a facilitator of discourse on important issues has been recognised by scholars working in different disciplines, especially in the arts and humanities. The challenge for the fourth generation is to apply indigenous epistemologies in our research 
and teaching, developing endogenous paradigms that reflect our contemporary context as African intellectuals participating in the global knowledge community.

I have articulated the mission of the fourth generation as the centring of African communities in intellectual production on and of Africa. This entails moving African intellectuals and forms of discourse 'from the margin to the centre' globally. As such, I am applying the term 'African Studies' here in a secondary sense to refer to all intellectual production by Africans. Africa's contribution to world civilisations did not end with the fall of ancient Egypt, nor have African intellectuals ceased to engage questions of a universal nature. This emerging generation must reflect in the content and methodology of its work the continuing relevance and importance of African intellectual thought to the whole world.

\section{Working Together}

The importance of inter-generational co-operation in working towards the success of the fourth generation cannot be discounted. There has been some progress in creating a nurturing environment for the fourth generation on the part of a number of individuals and organisations like CODESRIA. But the truth of the matter is that there is still much to be done. While we acknowledge all that has been done it is still far too early to

...sing

a PraiseSong for Our People.

For

There is no genuine praise except

Where great battles are won.

No deserving praise except

Where great despairs are blown apart.

(And so) Before the Praise [the ancient dirge singers] say

I must remind our people

Of our many, many Failures.

Before the praise they say

Such ample room for Blame \& Shame.

So much Pain before the Dawn of Joy.

Pain to measure our many blunders by

Blame to count\&count until our fingers break (Anyidoho, 2002: 55).

In her review of the current state of higher education in Africa, Takyiwaa Manuh concurs with researchers who conclude that our institutions of higher education have lagged behind other African organisations serious about insti- 
tutional reform with regard to gender. The cause of generational affirmative action is likely to suffer from a similar fate unless we take the issue of organisational reform seriously. We need to 'interrogate our institutional cultures and practices, [including our] management policies, power relations, resource allocation and division of labour [in the adoption] of equal opportunity policies' (Manuh 2002: 46). I suggest that we base our commitment to the development of the fourth generation on a covenant of mutual understanding, that will move us beyond the current intellectual climate which Issa Shivji laments as being far removed from the 'total absence of intellectual hierarchy' and 'joyful exchange[s]' that characterised the relationship between scholars such as Abdulrahman Mohammed Babu and Walter Rodney and those they mentored (Shivji 2003: 110). Such mentoring relationships, today an all too rare phenomenon within the academy, should become the goal of all scholars committed to the nurturing of the fourth generation.

Some scholars have expressed their discomfort with the encouragement of generational projects, which they see as taking away from involvement in a collective cross-generational agenda. However, as the then CODESRIA president Zenebeworke Tadesse emphasised in her closing remarks to the 2003 East Africa sub-regional CODESRIA conference, generational discourses need not result in generational division. The mission of the fourth generation is neither unique nor unrelated to those of preceding generations. It is a specific task in response to the peculiarity of the historical context in which its members find themselves, made possible only by the foundational work of those who have gone ahead. The fourth generation is simply under commission to build on the legacy that is its heritage from the past, with equal responsibility to prepare the foundation for the mission of those following. This is why we must think seriously about the question posed by Manuh at CODESRIA's international symposium on Canonical Works and Continuing Innovation in the African Arts and Humanities: 'How are we nurturing the next generation of scholars?' ${ }^{10}$

I challenge the first three generations of African scholars represented in this gathering [CODESRIA's 30th Anniversary] to take on the task of nurturing the fourth. Let me at this point break with scholarly protocol and address you directly, suggesting a number of ways in which you can each personally demonstrate your commitment to those of us who self-identify as belonging to the fourth generation.

First, you can nurture the fourth generation by passing on to us the intellectual heritage you hold in trust from the generations of African intellectuals who have preceded you. I am here not talking about just those who have been schooled with the western traditions of the post-independence 
African academy. I am including here the entirety of our intellectual legacy, dating as far back as we can trace it, through the different eras of our past. It is important that this inheritance be passed on, along with the tools and preparation to engage it exhaustively. Nuanced understandings must be cultivated from informed exploration of relevant aspects of the historical, socio-cultural and intellectual contexts of these discourses. ${ }^{11}$ This will entail 'going back to go beyond the usual suspects' to use Femi Taiwo's words, undertaking a recovery or re-evaluation of important work previously ignored, dismissed or simply neglected. It will also mean that you take us back into an exploration of significant debates that keep recurring within the academy, ${ }^{12}$ helping us to make our own contributions to them in the present contexts that we engage. Introduce us to seminal reflections on the African academy. Move such interventions as "The Kampala Declaration on Intellectual Freedom and Social Responsibility" out of library archives, through introductory courses offered in every department at both undergraduate and graduate level, into the everyday life of the academic institutions on this continent.

Secondly, you need to demonstrate your own commitment to the work of your peers - those still actively working within the academy-in your own research and teaching. Our centring of African communities must be carried out from a current, relevant and constantly updated resource base, itself testimony to the quality work that African communities are even now producing through our own institutions. As Francis Njubi (2003) points out, if a paradigm shift is to occur in the study of and by African communities, such discourses must be decoupled both from Eurocentric moorings and any ahistoric Afrocentric alternatives denying, ignoring or downplaying an African presence and present. This does not mean a blind rejection of the work of the rest of the global community. It does mean however, that careful attention must be paid to the politics of citation. We must ensure that hitherto marginalised communities are well represented in pedagogy and research. Beginning with those continental scholars whose work is ignored elsewhere, we need to pay particular attention to those who are subordinated within our own academy because of institutional biases with regard to gender, language and methodological differences. ${ }^{13}$

Thirdly, you can nurture the fourth generation by deliberately facilitating the creation and maintenance of an enabling environment for alternative pedagogical strategies. The kind of apprenticeships that were the strategy of choice in many African communities in the training of creative intellectuals ought to become a standard feature of African institutions of higher education. Isidore Okpewho (1992) establishes both formal and informal mentoring 
as the cornerstone of educational frameworks in the vast majority of indigenous African communities. Adopting them means going beyond the stipulated duties of formal academic mentoring in, say graduate student-advisor or junior-senior faculty relationships. It means a personal commitment that may well involve individual sacrifice, but that fosters mutual respect facilitating genuine dialogue in inter-generational partnerships. Committed mentors create opportunities for theory to move into practice by involving younger scholars in all aspects of their academic endeavours. They invite partnerships in editing material, writing proposals, and other aspects of organising and participating in scholarly forums. I have argued that the fourth generation need to take from those who are going ahead. I insist in return that you must be willing and eager to receive from, and give due credit to those who follow, thus establishing transformative mentorships that benefit both parties in the relationship.

In his analysis of Francis Imbuga's creative work, John Ruganda attributes Imbuga's 'flowering' to the creative and critical atmosphere he found during his undergraduate years at the University of Nairobi. Ruganda pays special attention however to Imbuga's mentoring by dramatist Joe de Graft, then a senior lecturer at the university, which he refers to as 'the most significant event to the young playwright' during his time there. Ruganda adds, [Joe] de Graft 'as a teacher ... encouraged his students to experiment [and] never suffocated younger and greener talent'. Though this tribute refers to de Graft's contribution to the Drama Studio in Ghana, it is equally pertinent to his work in Kenya. Imbuga established a long-lasting friendship with de Graft, which culminated in the latter recommending Imbuga for a UNESCO scholarship to further his education in drama and theatre. This bond of friendship is also mirrored in de Graft's creation of the challenging character of the Second Son in his play Muntu specifically for Imbugawhom he had come to trust as a reliable and competent actor. In turn, Imbuga wrote a student's guide to the same play by his mentor. Aware of Imbuga's ability at improvisation, de Graft suggested that he explore it for his postgraduate degree (Ruganda 1992: xv-xvi, citation, Micheal Etherton).

We need more Joe de Grafts. ${ }^{14}$

Similarly, I challenge myself, and the rest of the fourth generation, to take responsibility for our own nurturing. We cannot sit back and simply wait to become the next generation of African scholars by default. Instead of bemoaning the constraints that we face - and they are many - we need to exploit the resources that are available to us, both human and material, enabling us to take hold of opportunities unavailable to preceding generations. We must play our part on facilitating mutually beneficial partnership with 
histories similar to ours. We must pay particular attention to the African Diaspora in this regard. ${ }^{15}$ On the continent, we must work towards sustaining inter-generational cooperation, even as we seek out, create and participate in intra-generational forums which allow us to actively engage each other and so facilitate individual and group involvement in the carrying out of our mission.

I am aware that, all too often, frustration has resulted from negative experiences of academic bullying, especially through the 'peer' review process. This has led in some cases to a disdain and disrespect for preceding generations that we expertly mask outside our 'safe spaces'. Part of our reality is knowing, as Elikia M'Bokolo has observed, that many of our own teachers are themselves presently incapable of providing the kind of nurturing we seek. ${ }^{16}$ Presumably this is because they themselves have been the victims of poor preparation, lack of resources and years of systematic repression and oppression by both state and international agencies. It must be granted that some will always neither be able nor willing to do their part in nurturing those who follow them. Fanon however urges us not to give in to the temptation of a blanket dismissal of everything and everyone who has preceded us:

We must rid ourselves of the habit, now that we are in the thick of the fight, of minimising the action of our [mothers and] fathers and of feigning incomprehension when considering their silence and passivity. They fought as well as they could, with the arms they possessed then; and if the echoes of their struggle has not resounded in the international arena, we must realise that the reason for their silence lies less in their lack of heroism than in the fundamental different international situation of our time (Fanon 1967: 166).

While we must learn to refuse to give in to academic bullying and other forms of intimidation that will hold us back from meeting the challenges we face, we can seek out those who are can and do provide positive mentoring and support experiences thereby fostering enabling environments for us to benefit from.

Most of us work under conditions of material constraint; even those located in the affluent West/North starve for lack of access to resources, by and most relevant to African communities. However, we can look at the possibilities afforded us by the accident of time that has placed us in this particular historical context. On one hand, we must grapple with the challenges of globalisation, on the other, as Edward Waswa Kisiang'ani argues, we can take advantage of it (Kisiang'ani 2002). The IT revolution has made it possible for example to improve networking between institutions and individuals, and to make available resources that were hitherto difficult if not 
impossible to access. The Internet has the potential to become one of our greatest aides in the important project of creating and maintaining support systems crucial to the facilitation of intra-generational partnerships. Fostering a healthy environment for exchange and cooperation amongst ourselves is foremost among the tasks we face in the accomplishment of our mission.

We must also take advantage of the present challenging of hegemonic ideologies within the academy, which enables the transcending of boundaries long part of the legacy of imperialism haunting the African academy. This involves confronting geographical, gender, linguistic, religious, regional, racial, ethnic, institutional and other realities that have kept African thinkers of both continent and diaspora divided up into intellectual 'blocs'. Even as we continue to work within contexts of particular institutional, national and regional identities and histories, we need to develop a collective sense of belonging to a bigger whole, a project that brings our diversities into a unity based on dialogue and mutual respect.

Finally, we need to discover and pursue new ways of working that are relevant and particularly adapted to the environments within which we work In other words, we must commit ourselves to 'work out our own salvation', if not in fear and trembling, then certainly with dedication and purpose.

As we, all four generations of African scholars of the post-independence era, join together in doing our part in nurturing the fourth generation,

Let us mix the long memories of a people destroyed with new narratives of our own making, as we move into space of our own choosing, as we dream in images woven from our people's best desires, as we plan on designs drawn from our own reflection, then make again the universe that might have been but was not, here in this place, now in this time freed for our new creation ...

Let us walk together, invoking the future into now (Armah 2002: 12).

\section{Notes}

1. Several scholars have responded to the challenge of identifying generations of intellectuals within the African academy. Some have chosen to confine themselves within specific boundaries, for example, Ngugi wa Thiong'o whose understanding of intellectuals as 'interpreters' in Penpoints, Gunpoints and Dreams focuses on words as the medium through which ideas are fashioned and David Donkor who explores a specific context (Ghanaian theatre) in his paper 'PanAfricanism, Nationalism and Theatre Discourse in the New Political Economy of Ghana'. I have chosen to specifically engage Mkandawire's reflections on this issue, since these emerge within the context of CODESRIA discourse and are of a more general nature. 
2. I acknowledge in particular Nana Akua Anyidoho, Ato Kwamena Onoma, David Donkor, Godwin Murunga, David Ndii, Francis Njubi, Hannington Ochwada, Alphonse Otieno and Praise Zenenga.

3. To give one example, as one observer remarked to me, the Institute of Economic Affairs (Kenya) currently has more influence with the present Kenyan government in matters of national policy formulation than any university department or faculty in the country. In 2003 as I was preparing this presentation, public universities in Kenya were closed by government directive, following the commencement of a strike by academic staff. In the first three days of the strike, I counted no less than five presentations by major news media organisations, using 'ivory tower' as a synonym for the 'university' in either their headlines or programme titles.

4. In its editorial on the above strike, The East African paper, a respected regional weekly, supports the University Academic Staff Union's demands, but then, comments in a reflection of popular perceptions: 'Currently, very little cuttingedge is coming out of ... universities, which take a big proportion of the ... education budget, that itself accounts for a third of the public expenditure'. The East African further argues, '[I]t will be important for the lecturers ... to ensure that they move to salvage the reputation of their profession ... The common joke is that because of lack of research, many lecturers continue to plagiarise and publish the theses written by their students - which are often themselves recycled drivel - to meet the requirements of academia and keep up a facade of respectability' (12).

5. Individual experiences of this drawn from different parts of the continent recorded in Words Behind Bars and the Paradox of Exile.

6. Witnessed for example by Paul Tiyambe Zeleza in Malawi.

7. Godwin Murunga explores the different responses and the consequences thereof with regard to Kenyan intellectuals, especially those with radical persuasions in 'Democratisation in Kenya: Thinking Through the Crisis of Radicalism'.

8. Imbuga, Mutahi and Yankah all became hugely popular with newspaper readers for their keen, hilarious observations of daily life in Kenya and Ghana respectively. Their creative work (the cartoon-strip 'Nyam Nyam' [Imbuga] and humour columns 'Masharubu's World' [Imbuga] 'Whispers' [Mutahi] and 'Woes of a Kwatriot' [Yankah]) is perhaps best described by the intriguing title of Yankah's ethnography of free speech, 'We Bite while We Blow'. Imbuga and Mutahi are also well known for their dramatic social satires; the most wellknown of the latter's are in the Gikuyu language.

9. Amina Mama emphasises the importance of this in relation to gender studies.

10. The CODESRIA symposium on Canonical Works and Continuing Innovation in the African Arts and Humanities was held at the Institute of African Studies, University of Ghana at Legon on September 17-19, 2003.

11. See, for example, Ato Kwamena Onoma's reflection in this collection, 'African Scholarship, Language and Democracy: The Struggle for Participatory and 
Inclusionary Politics in Africa', as it explores the contexts influencing the role of the intellectual with regard to issues of language and democracy.

12. See, for example, Nana Akua Anyidoho's paper on this collection, 'Identity and Knowledge Production in the Fourth Generation', which re-visits the issue of insider scholarship.

13. As Rudo Gaidzanwa points out in her investigation on the gender disparity in the canon-makers of the early independence period, the imbalances within the colonial period (carried on after political independence in many cases) with regard to opportunities for western education at the expense of girls and women. This disparity in opportunities also exist(ed) with regard to ethnic, religious, political and other minorities, resulting in similar imbalances in their representation within the African canon still evident today in every discipline in the academy.

14. Imbuga, previously Dean of the Faculty of Arts, and head of the Department of Literature, Kenyatta University was, at the time of writing this article, based in Rwanda working on curriculum development, still following his mentor's commitment to working on a continental level.

15. See Godwin Rapondo Murunga's paper in this collection, 'Thoughts on Intellectual and Institutional Links between African and Black Studies'.

16. Plenary discussion, The CODESRIA symposium on Canonical Works and Continuing Innovation in the African Arts and Humanities.

\section{References}

Abah, S. O., 1997, Performing Life: Case Studies in the Practice of Theatre for Development, Zaria: Shekut Books.

Anyidoho, K., 2002, 'Praise Song for The Land', in Praise Song for The Land, Accra: Sub Saharan Press.

Anyidoho, K., ed., 1997, Word Behind Bars and the Paradox of Exile, Evanston, Il: Northwestern University Press.

Anyidoho, N. A., 2003, 'Identity and Knowledge Production in the Fourth Generation', Mans. Dakar, Senegal.

Armah, A. K., 2002, Kmt: In the House of Life, Popenguine: Per Ankh.

Collins, P. H., 2002, Black Feminist Thought: Knowledge, Consciousness and the Politics of Empowerment (2nd Edition). New York: Routledge.

Donkor, D. A., 'PanAfricanism, Nationalism and Theatre Discourse in the New Political Economy of Ghana', Mans. Dakar, Senegal.

'Editorial: Pay Dons Well and Work Them', in The East African, November 17-23, 2003. Nairobi: Nation Media Group.

Fanon, F., 1967 [1963], The Wretched of the Earth, Harmondsworth: Penguin.

Gaidzanwa, R., 2003, 'Gender and Canon Formation: Women and Men and Literary Art in Africa', Mans. Accra, Ghana. 
Hountondji, P., ed., 1997, Endogenous Knowledge: Research Trails. Dakar: CODESRIA.

Imam, A. et al., 1997, Engendering African Social Sciences, Dakar: CODESRA.

Kisiang'ani, E. W., 2002, 'The Youth and African Heritage in the New Millennium: Some Reflections,' in CODESRIA Bulletin, nos. 3 \& 4.

Mama, A., 2003, 'Gender Studies for Africa's Transformation', Mans. Dakar, Senegal.

Manuh, T., 2002, 'Higher Education and the Condition of Scholars and the Future of Development in Africa', in CODESRIA Bulletin, nos. 3 \& 4.

Mkandawire, T., 1997, 'The Social Sciences in Africa. Breaking Local Barriers and Negotiating International Presence', in African Studies Review, Vol. 40, no. 2.

Mkandawire, T., 1995, 'Three Generations of African Scholars: A Note', in CODESRIA Bulletin, no. 2.

Mugo, M. G.. 1996, 'Response to Philip D. Curtin on 'Ghettoizing African History', in Association of Concerned Africa Scholars Bulletin, no. 46.

Murunga, G. R., 2003, 'Democratisation in Kenya: Thinking through the Crisis of Radicalism', Mans. Addis Ababa, Ethiopia.

Murunga, G. R., 2003, 'Thoughts on Intellectual and Institutional Links Between African and Black Studies', Mans. Dakar, Senegal.

Mutahi, W., 2002, Fourteen 'Whispers 'Stories, Nairobi: Consolata Missionaries.

Mutahi, W., 1996, How to be a Kenyan, Nairobi: Kenway Publications.

Mutahi, W., 1991, Three Days on a Cross, Nairobi: Heinemann.

Njubi, F., 2003, 'Loose Canons: Space, Race and Nation in African Studies', Mans. Accra, Ghana.

Okpewho, I., 1992, African Oral Literature: Backgrounds, Character and Continuity, Bloomington: Indiana University Press.

Olukoshi, A., 2003, 'Hope for a New Millennium', in CODESRIA Bulletin, nos. $3 \& 4$.

Onoma, A. K., 2003, 'African Scholarship, Language and Democracy: The Struggle for Participatory and Inclusionary Politics in Africa', Mans. Dakar, Senegal.

Richards, S. L., 1996, Ancient Songs Set Ablaze: The Theatre of Femi Osofisan, Washington D.C.: Howard University Press.

Ruganda, J., 1992, Telling the Truth Laughingly: The Politics of Francis Imbuga's Drama, Nairobi: East African Publishing House.

Sall, E., ed., 2002, Women in Academia: Gender and Academic Freedom in Africa, Dakar: CODESRIA.

Sall, E., 2003, The Social Sciences in Africa: Trends, Issues, Capacities and Constraints, SSRC Working Paper Series on Building Intellectual Capacity for the 21 st Century, Vol. 8.

Sall, E., et. al., 2003, 'The Public Dimensions of the University in Africa', Journal of Higher Education in Africa, Vol. 1, no.1.

Shivji, I. G., 2003, 'The Life and Times of Babu: The Age of Liberation and Revolution', in Review of African Political Economy, no. 95.

Sweet Honey in the Rock, 1997, Selections. Cambridge MA: Rounder. 
Taiwo, F., 'Beyond the Usual Suspects: Towards Renewing the Foundations of African Philosophy', Mans. Accra, Ghana.

Veney, C. R. and Zeleza, P. T., eds., 2001, Women in African Studies Scholarly Publishing, Trenton, NJ: Africa World Press.

wa Thiong'o, N., Penpoints, Gunpoints and Dreams: Toward a Critical Theory of the Arts and the State in Africa, London: Clarendon Press.

Yankah, K., 1996, Woes of a Kwatriot: Beloved Let us Laugh, Accra: Anansesem Publications.

Yankah, K., 1996, Woes of a Kwatriot: No Big English, Accra: Anansesem Publications.

Yankah, K., 1995, 'We Bite While We Blow; An Ethnography of Free Speech in an African Culture', Mans. Michigan, Ann Arbor.

Yankah, K., 1990, Woes of a Kwatriot: Reflections on the Ghanaian Situation, Accra: Woeli Publishing Services.

Zeleza, P. T., 1997, Manufacturing African Studies and Crises, Dakar: CODESRIA. 